原

食道癌術後における輸液と経腸栄養を主体とした

$$
\text { 管理の有用性について }
$$

\begin{tabular}{llllll}
\multicolumn{2}{c}{ 岩手医科大学第 1 外科, 国立療養所盛岡病院臨床研究部病理病態研究室 } \\
池田健一郎 & 佐藤 信博 & 肥田 & 圭介 & 目黒 & 英二 \\
上杉 憲幸 & 小笠原 聡 & 大塚 & 幸喜 & 木村 & 祐輔 \\
前沢 千早* & 八重樫泰法 & 寺島 & 雅典 & 岡本 & 和美
\end{tabular}

石田 薰 斎藤 和好

胸部食道癌手術患者38名を対象に以下の術後輸液・栄責管理を施行し，うち14名で水分電解質代謝， 栄養指標を, 全例で術後合併症を検討した。輸液管理：Cardiac Index と End Diastolic Volume Index を術前值以上に保つよう細胞外液組成液を中心に投与. 栄責管理 : 末梢輸液と 3 病日からの経腸的栄 養投与.この結果, 0 病日の総投与水分・ $\mathrm{Na}$ 量は $5.24 \mathrm{ml} / \mathrm{kg} \cdot \mathrm{h}, 0.56 \mathrm{mEq} / \mathrm{kg} \cdot \mathrm{h}$ で 1 病日以降に比へ 有意に多く, 水分出納は 2 病日に最低值を示した。総投与カロリーは 9 病日に $30 \mathrm{kcal} / \mathrm{kg} \cdot \mathrm{day}$ を超元, 窒素, $\mathrm{K}$ 出納は10，4病日に正転した. Total protein, Albumin, Rapid turnover protein, リンパ 球数は 3 病日に最低值を, 3-MeHis, C-reactive protein は 3 病日に最高値を示し, 14病日には回復し た. 術後合併症発生率は, 不整脈 ( $8 \%$ ), 高ビリルビン血症 (11\%), 1 次性肺合併症 (11\%), minor leakage ( $3 \%$ ) だった. 以上より, 術後侵襲期は容量負荷による循環動態安定化を優先し, 侵襲離脱 後の生理的栄蔶投与で, 簡便で安全な術後管理が施行可能と思われた.

Key words: postoperative management for esophageal cancer, enteral nutrition, infusion therapy, postoperative complication of esophageal cancer

\section{はじめに}

胸部食道癌の外科治療は手術手技と周術期管理の進 歩によって, 3 領域拡大リンパ節郭清の適応症例も增 加し, 遠隔成績は向上したものの ${ }^{11}$, 今後さらなる遠隔 成績の向上には手術療法に加え，近年進歩してきた生 物学的悪性度判定 ${ }^{21}$ や制癌剂感受性試験 3 (4) を加味し た, 強力な化学療法や放射線療法を加えた集学的治 療 ${ }^{5 / 6)}$ が必要と考えられる.このためには食道癌術後侵 襲期の円滑かつ迅速な離脱によって, 術後補助療法の 早期導入・完遂が要求される，われわれは従来まで術 後早期は完全静脈栄養 (total parenteral nutrition: 以下, TPN と略記) 単独で十分なカロリー投与 $(20 \sim 40 \mathrm{kcal} / \mathrm{kg} \cdot \mathrm{day})$ を行い, 徐々に栄責投与の主体 を経腸栄養 (enteral nutrition：以下, EN と略記) に 移行する管理を施行してきた ${ }^{7)}$. しかし, 術後侵襲期の

$<1995$ 年 3 月 8 日受理 >別刷請求先：池田健一郎 T020 盛岡市内丸 $19-1$ 岩手医科大学第 1 外科
一律な TPN による栄養投与は, 周術期管理を繁雑と させるだけでなく，逆に生体にとって stress となり， そのために生じたと考えられる高血糖や血中尿素窒素 の上昇等の合併症がしばしば観察された。そこで過去 2 年間, 術後早期の輸液管理は循環動態の安定化を第 1 目標とし, 栄養管理は TPN を使用せず, 末梢輸液と 第 3 病日よりの生理的な EN の併用という管理方針 に変更した ${ }^{8)}$. 本稿では本管理法の有用性を水分電解 質代謝, 栄養学的指標の推移や術後合併症の観点から 検討した.

\section{対象と方法}

\section{1. 対象}

1991年 5 月～1994年 1 月の期間に岩手医科大学第 1 外科で右開胸開腹, 頸部操作による胸部食道全摘術を 施行した胸部食道癌患者のうち術前合併症のない 38 名 を対象とした，水分電解質代謝，栄養学的指標はこの うち14名で検討し, 下痢や術後合併症の発生率は全例 で検討した.なお，この間の手術は同一術者が施行し, 
Table 1 Patients' characteristics

\begin{tabular}{l|lr}
\hline sex & male : & 13 \\
& female: & 1 \\
\hline age & $59.9 \pm 10.0^{\mathrm{a}}$ \\
\hline lymph nodes dissection & 3 field extended : & 4 \\
& 3 field: & 1 \\
& 2 field: & 9 \\
\hline operation time & $358.2 \pm 85.3 \mathrm{~min}$. \\
\hline bleeding & $624.5 \pm 297.0 \mathrm{~g}$ \\
\hline TMN classification & \multicolumn{2}{|c}{} \\
Stage grouping (pathological) & $0:$ & 1 \\
& I: & 1 \\
& IIA : & 4 \\
& IIB: & 4 \\
R classification & III: & 4 \\
& R0: & 13 \\
& R2: & 1 \\
\hline
\end{tabular}

a ; mean \pm S.D.

$b$; " $\mathrm{R}$ " means the absence or presence of residual tumor after operation. R0; no residual tumor, R2 ; macroscopic residual tumor.

術後呼吸管理は, 経鼻挿管下に respirator を接続し, 自発呼吸下に pressure support ventilation と持続陽 圧換気による補助呼吸を術直後から $2 \sim 3$ 病日朝まで 施行した。水分電解質代謝, 栄養学的指標を検討した 14名の背景因子は別表に示した（Table 1).

\section{2. 輸液・栄養管理の方法}

術前は経口捸取と必要に応じ EN を併用し, 術前日 夕までは $1,800 \mathrm{kcal} / \mathrm{day}$ を目安に経腸的栄養投与を行 い, 手術 3 日前より $2 \mathrm{ml} / \mathrm{kg} \cdot \mathrm{hr}$ 以上の末梢輸液を施行 した. 全例, 術中に Treitz 勒帯から $20 \sim 30 \mathrm{~cm}$ の空腸 に8Frの ED tube を用いて tube jejunostomy を造設 した. 術中輸液は, 細胞外液組成液を $12 \sim 15 \mathrm{ml} / \mathrm{kg} \cdot \mathrm{hr}$ で投与した。術直後からの輸液管理は, Swan-Ganz catheter 挿入下に循環動態をモニタリングしつつ, 細 胞外液組成液を中心に cardiac index（以下, CI と略 記) と right ventricular end diastolic volume index (以下, EDVI と略記) を術前值以上に保つように投与 した.グルコースは 5 10g/hrで投与した。膠質製剤は Colloid Osmotic Pressure (以下, COP と略記) 20 $\mathrm{mmHg}$ 以上を目標に投与した. dopamine, dobutamine は適宜使用した。また, 栄養管理は, 経腸 栄養㨈としてクリニミール®9)用い 3 病日より 5 $\mathrm{kcal} / \mathrm{kg} \cdot \mathrm{day}$ より開始し，腸管運動や排便状態を観察 しながら $5 \mathrm{kcal} / \mathrm{kg} \cdot$ day ずつ増量し，10〜 14病日に30 $\mathrm{kcal} / \mathrm{kg}$-day 以上の full strength とすることを目標 とした.

3. 水分電解質代謝, 栄養学的指標等の検討項目 術後は連日蓄尿し, 24時間尿の一部を採取し, 尿中 電解質, 総窒素を測定した。これらの結果をもとに 7 病日までの総投与水分量, 総投与 $\mathrm{Na}$ 量, 1 次水分出納 を，14病日までの総投与カロリー (non-protein cal), 窒素出納, $\mathrm{K}$ 出納を算出した。 また, 術前, 1,3 , 7,14 病日の朝に血液一般検査, 血液生化学検查のほ か, 栄養学的指標として prealbumin (以下, PA と略 記), transferrin (以下, Tf と略記), retinol binding protein (以下, RBP と略記)の rapid turnover protein (以下，RTP と略記）を, 術前および $2,4,8,15$ 病日の朝に前日の 24 時間㲾の一部を採取し, 筋蛋白崩 壊の指標として尿中3-methyl histidine（以下，3$\mathrm{MeHis}$ と略記）を測定した。

4. 統計学的手法

各測定值, 数値は平均 $( \pm$ S.D.) で表した. 統計学的 有意差の検定は,コンピューターソフト Stat View 4.0 (Abacus Concepts, Inc.) を用い, 経時的変化に おける有意差の検定は, student paired t-test を用い, $\mathrm{p}<0.05$ の場合に有意差有りとした。

\section{結 果}

1. CI, EDVI, 総投与水分量, 総投与 $\mathrm{Na}$ 量, 1 次 水分出納の推移

本管理における実際のCI, EDVIの推移を示した (Fig. 1).CI は経過中すべての測定 point で術前値以 上の值で推移しており, 特に $1 \sim 2$ 病日には術前値に 比較して有意な高值 $(\mathrm{p}<0.05)$ で推移していた。 また, EDVI は術直後に軽度の低下を認めたものの, 以後ほ とんど術前值と同等な值で推移しており有意な変動は 認められず, プロトコール通りに輸液管理が可能で あった．実際に投与された術後の総投与水分量，総投 与 $\mathrm{Na}$ 量は 0 病日でそれぞれ $5.24 \pm 1.09 \mathrm{ml} / \mathrm{kg} \cdot \mathrm{hr}$, $0.56 \pm 0.11 \mathrm{mEq} / \mathrm{kg} \cdot \mathrm{hr}$ と 1 病日以降に比較して有意 に多い投与量であった $(\mathrm{p}<0.01)$.また，1次水分出 納は 0 病日に+1,700 $1,182 \mathrm{ml}$ と最大值を示した後 漸減し 2 病日には $+221 \pm 1,319 \mathrm{ml}$ と最低値を示し, 1 $\sim 3$ 病日のバランスは， 0 病日に比べ有意な低值を示 した $(1,2$ 病日は $\mathrm{p}<0.01 ， 3$ 病日は $\mathrm{p}<0.05)$ (Fig. 2).

2. 総投与カロリー, 窒素出納, $\mathrm{K}$ 出納の推移

末梢輸液による投与カロリーは14病日までほ沽一定 であり，1 日平均 $7.32 \mathrm{kcal} / \mathrm{kg}$ であった．末梢輸液と 
Fig. 1 Postoperative changes of cardiac index (CI) and right ventricular end diastolic volume index (EDVI). CI on 1 and 2POD was significantly higher than that of preoperative value ( $\% ; \mathrm{p}<0.05$, paired t-test). $a$; mean + S.D.
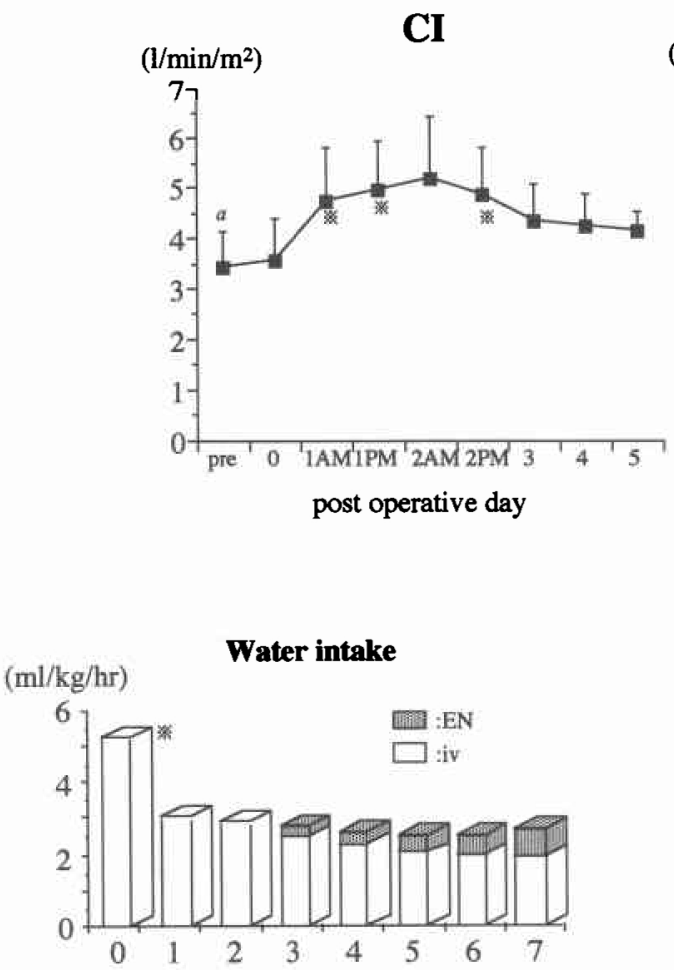

Na intake
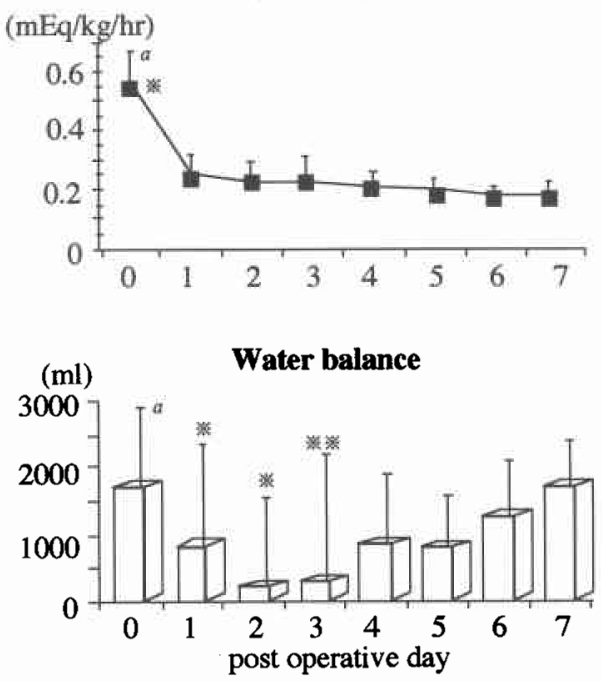

$\mathrm{EN}$ による総投与カロリーは，9病日には $30 \mathrm{kcal} / \mathrm{kg} ・$ dayを超え12病日には $35 \mathrm{kcal} / \mathrm{kg} ・ \mathrm{day}$ 以上投与可能 であった.窒素出納は, 1 病日に $-8.33 \pm 2.27 \mathrm{~g} / \mathrm{day}$ と

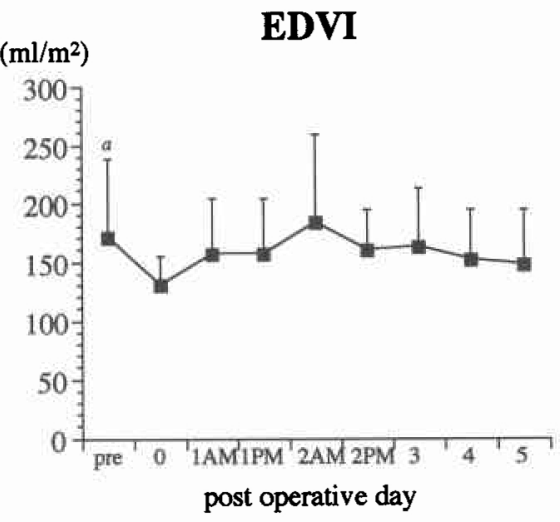

Fig. 2 Postoperative water intake, sodium intake and water balance. Water intake indicates total amount of intravenous and enteral feeding. Water intake and sodium intake on the first postoperative day indicated significantly higher than those on following days $(\% ; p<0.01$, paired t-test). Water balances on 1,2 and 3POD were significantly lower than that of 1POD ( $\% ; \mathrm{p}<$ $0.01, ※ \% ; \mathrm{p}<0.05$, paired t-test). $a ;$ mean + S.D.

最低值を示した後, 徐々に改善し，10病日には正転し た. $\mathrm{K}$ 出納は窒素出納より早く, 1 病日に最低值を示 し，以後改善して 4 病日には正転した（Fig. 3).

\section{3. 各種検査成績の推移}

（1）血清総蛋白 (以下, TP と略記)，アルブミン, 尿素窒素 (以下, BUN と略記), クレアチニン (以下, CRNN と略記）の推移

TP とアルブミンはほほ同様な推移で, 1,3 病日で は術前值に比較して有意な低值を示したが（p< 0.01)，7病日以降は術前值と同等の值に推移してい た。なお， $0 〜 7$ 病日までの 8 日間における新鮮凍結 人血漿 (以下, FFP と略記)，アルブミンの総投与量は それぞれ15.8土8.5単位, $78.4 \pm 41.1 \mathrm{~g}$ であった. BUN と CRNN は術後正常範囲内で大きな変動なく推移し た (Fig. 4).

(2) C-reactive protein (以下, CRP と略記), 末梢 血リンパ球数の推移

侵襲の指標として $\mathrm{CRP}^{(0)}$ と末梢血リンパ球数 ${ }^{11)}$ 
Fig. 3 Postoperative total calorie intake, nitrogen balance and potassium balance. Total calory intake reached $30 \mathrm{kcal} / \mathrm{kg} /$ day on $9 \mathrm{POD}$. The nitrogen and the potassium balance became positive on 10 and $4 \mathrm{POD}$, respectively. $a$; mean \pm S.D.

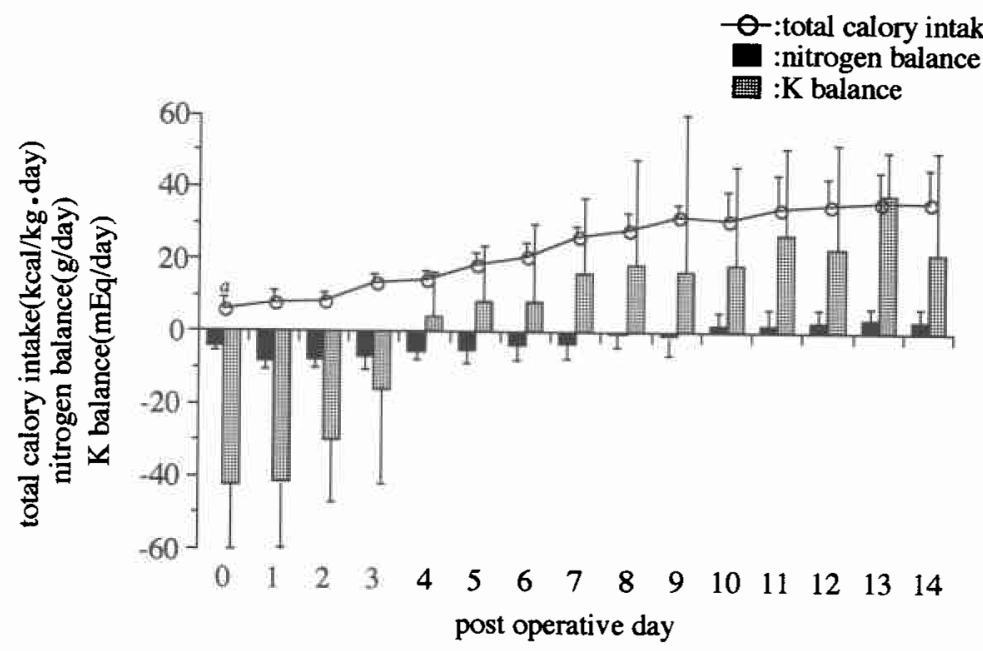

Fig. 4 Postoperative changes of total protein (TP), albumin, BUN and creatinine (CRNN). TP and albumin values on 3 and 7POD were significantly lower than those of preoperative values (\%; $\mathrm{p}<0.01$, paired t-test). BUN and CRNN values changed within normal range. $a$; mean \pm S.D.

\section{TP, Albumin}

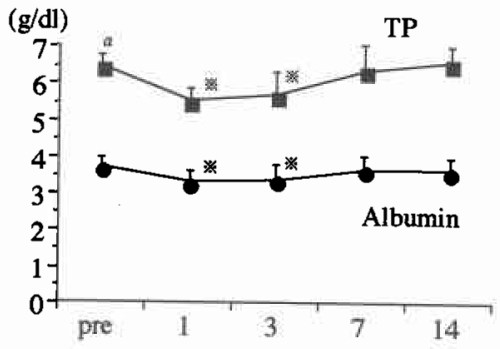

BUN, CRNN

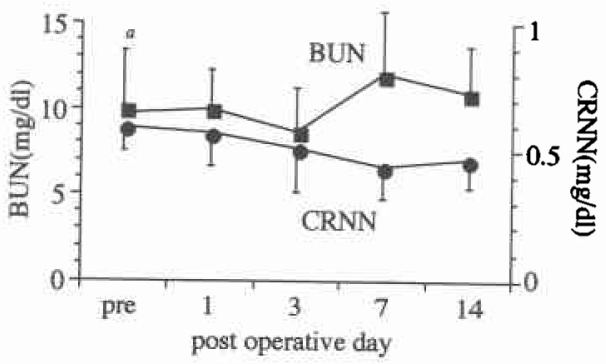

測定した. CRP は $1 \sim 7$ 病日までは術前値に比較して 有意な高値を示し $(\mathrm{p}<0.01)$, 特に 3 病日には $20.7 \pm$ $7.70 \mathrm{mg} / \mathrm{dl}$ という最高値に達した後14病日には術前 値と同等な値に推移していた. 末梢血リンパ球数は CRP とは逆に 1〜 7 病日までは有意な低値を示し $(\mathrm{p}<0.01), 3$ 病日に $786 \pm 221 \mathrm{cells} / \mathrm{mm}^{3}$ という最低值 を示した後漸増し，14病日には回復した（Fig. 5)。

(3) RTP の推移

$\mathrm{RTP}$ の推移は PA, Tf, RBP とも同様な推移を示 し, 3 病日に有意な最低值 $(\mathrm{p}<0.01)$ を示した後徐々 に改善し，14病日にはPA 以外は術前値と同等な値に まで改善していた（Fig. 6).

（4）尿中3-MeHis 排泄量の推移

尿中3-MeHis 排泄量は $1 \sim 7$ 病日まで術前值に比 較し有意な排泄量の増加を認め $(\mathrm{p}<0.01) ， 14$ 病日に は術前値と同等な排泄量に推移していた（Fig. 7).

\section{4. 下痢の発生日数}

術後は 2 病日よりワゴスチグミンなどの投与により 積極的な腸管蠕動の六進を目指すとともに早期離床を 励行させた結果, 腹部膨満や便秘が原因で EN の投与 量の減量を強いられた症例は認めなかった。投与量の 隇量はむしろ下痢に起因することが多く，14病日まで の下痢の日数を EN 群の全症例 (38名) で検討すると, 0 日5 $/ 38(13 \%) ， 1 \sim 2$ 日 $13 / 38(34 \%) ， 3 \sim 4$ 日11/ 38 (29\%)，5 日以上 $9 / 38$ (24\%) であった。 5 日以上 
Fig. 5 Postoperative changes of CRP and peripheral lymphocyte count. CRP value on 1,3 and 7 POD was significantly higher than that of preoperative value ( $; \mathrm{p}<0.01$, paired t-test). Peripheral lymphocyte counts on 1,3 and 7 POD were significantly lower than those of preoperative counts $(\% ; \mathrm{p}<0.01$, paired t-test). $a$; mean + S.D.

CRP
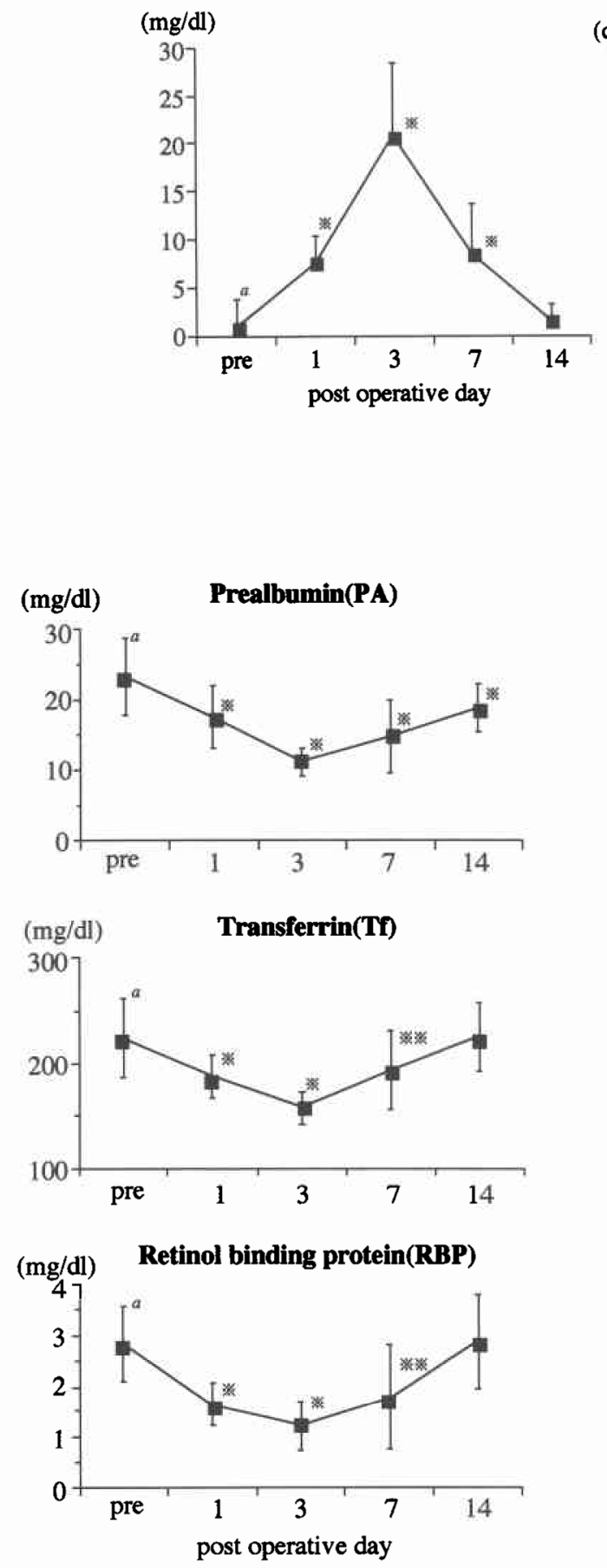

\section{Lymphocyte}

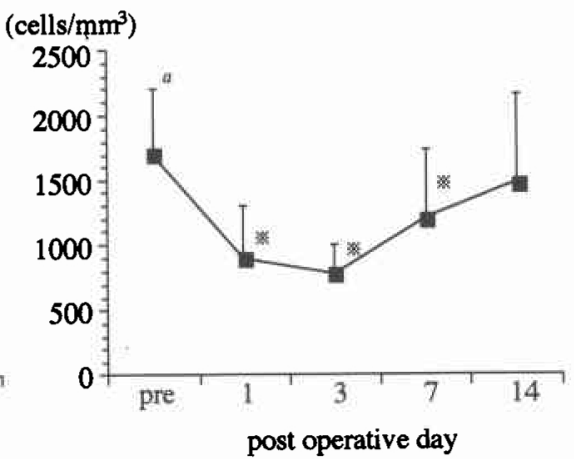

Fig. 6 Postoperative changes of prealbumin (PA), transferrin (Tf) and retinol binding protein (RBP). These three parameters changed similarly. Asterisks indicate significant differences versus preoperative value $(\% ; p<$ $0.01, ※ \cdots ; \mathrm{p}<0.05$, paired t-test). $a ;$ mean \pm S.D.

Fig. 7 Postoperative changes of 3-Metyl Histidine (3-MeHis) urinary excretion. Its value on 1,3 and 7POD was significantly higher than that of preoperative value ( $\% ; \mathrm{p}<0.01$, paired $\mathrm{t}$-test). $a ;$ mean + S.D.

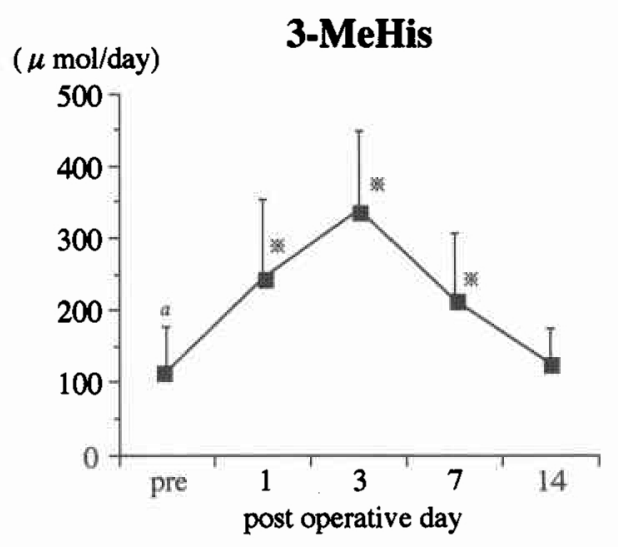

の下痢を認めた 9 名のうち 3 名では EN 投与量の減 量を余儀なくされたが, 他の症例では減量した例は認 めなかった。 
Table 2 Postoperative complications

\begin{tabular}{l|l}
\hline primary pulmonary complication $^{\mathrm{a}}$ & $4 / 38(11 \%)$ \\
arrythmia $^{\text {hyperbilirubinemia }}{ }^{\mathrm{b}}$ & $3 / 38(8 \%)$ \\
minor leakage & $4 / 38(11 \%)$ \\
ileus & $1 / 38(3 \%)$ \\
\hline
\end{tabular}

a ; indicates atelectasis, ARDS, and pneumonia

$\mathrm{b}$; serum total bilirubin level $>2.5 \mathrm{mg} / \mathrm{dl}$

\section{5. 術後合併症発生率}

術後合併症は無気肺, adult respiratory distress syndrome (以下, ARDS と略記), 肺炎を含む 1 次性 肺合併症および総ビリルビン値 $2.5 \mathrm{mg} / \mathrm{dl}$ 以上の高ビ リルビン血症がおのおの38例中 4 例 $(11 \%)$ に認めら れた。また, minor leakage は 1 例 ( $3 \%)$ ，不整脈は 3 例（8\%）に認めた.イレウスを 1 例に認めたが, これは ED tube 刺入部の癒着, 軽度の捻転に起因した ものであり, $\mathrm{EN}$ 投与には支障なく, 24 病日に癒着はく 離を施行し軽快した（Table 2).

\section{考 察}

過大侵襲を伴う胸部食道癌術後には呼吸・循環・栄 養管理を中心とした全身管理が要求される。呼吸管理 に関しては, 予防的人工呼吸管理 ${ }^{5}$ や気管支ファイ

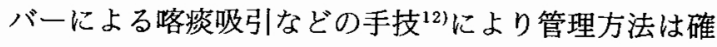
立されてきている.しかし, 循環管理は dry side ${ }^{13)}$ と wet side ${ }^{1415)}$ の管理の両者の報告があり，いまだ定説 を得ていない，また，栄養管理に関しても，近年の高 度侵襲下の代謝動態の検討 ${ }^{16)}$ や経腸栄養法の進歩 ${ }^{17)}$ に より, 従来の術後早期からの TPN による一律な高力 ロリー輸液施行という栄養管理法が見直されつつあ る $^{18) ~ 20)}$. 以前より我々は, 術後早期の hypovolemia 主体とした循環不全が third space loss を増強し, 酸 素捸取能の悪化による酸素消費量の低下を招き, 術後 合併症の発生と密接に関連することを指摘してお $\eta^{12)}$, TPN による高力ロリ一輸液を併用しつつ十分 量の輸液を投与するように心掛けてきた。しかし， TPN による血糖の上昇とインスリン投与量の増大, 血清 BUN の上昇や肝機能障害, さらには血清高浸透 圧に伴う脱水などを認める症例にしばしば遭遇し，高 度侵襲による体液・電解質変動の大きな食道癌術後に おいてこれらの代謝上の stress は hypovolemia を助 長し, 容易に循環動態の破綻を来し, 重篤な合併症の 引き金となる可能性が考えられた。そこで我々は，術 直後は life threatening factorである呼吸循環不全の
予防を最優先とし, 輸液管理は, 高力ロリ一輸液を併 用せず, 細胞外夜組成液を中心とした十分量の輸液と 膠質製剂で有効循環血液量の維持をはかることによ り, 末梢・臟器循環の改善, 遷延性低酸素血症の予防, 術後乏尿期の短縮と利尿期の早期終了という侵襲期の 早期離脱に努め, 栄養療法は侵襲の離脱後 3 病日から 生理的栄養法である ENを開始する管理に変更し た ${ }^{8)}$.

今回は本管理法の有用性について水分電解質代謝, 栄養指標および術後合併症発生率より検討した。本管 理における輸液量の指標は, CI と EDVI の容量指数を 用い,これらを術前值以上に保つような輸液を施行す るとともに dopamine, dobutamine の適宜使用により 心機能の維持に努めた。実際のCI 抢よびEDVIの推 移は良好であり (Fig. 1), 特に $1 \sim 2$ 病日は hyperdynamic な循環動態を呈していた。これは, CI と EDVI を術前値以上に保つように輸液を施行した結 果, 1 病日以降に比較して有意に多い 0 病日の水分・ $\mathrm{Na}$ 投与量の refilling によるものと考えられた。また， $\mathrm{Na}$ 投与量は細胞外液組成液と FFP の投与に付随し た結果であり, 决して高 $\mathrm{Na}$ 濃度の輸液を施行したわ けではなく, 高 $\mathrm{Na}$ 濃度輸液に伴って発生すると考え られる腎機能障害 ${ }^{211}$ は BUN, CRNN の推移を見る限 りでは認められなかった(Fig. 4)。これらの期間中, 心不全や肺水腫を呈した例は認められず, 逆に, 術直 後より十分な利尿と循環動態の安定化が認められ, hypovolemia に起因すると思われる不整脈は, ほとん ど認められなかった. 1 次水分出納は 2 病日を中心に $1 \sim 3$ 病日で 0 病日に比べ有意な低值を示し, 乏尿期 の短縮と利尿期の早期終了を認めた。また, 侵襲の指 標である CRP, 末梢リンパ球数の推移も 3 病日を境に 好転する傾向を認め (Fig. 5), 侵襲の早期離脱に伴い respirator からの離脱も多くの症例で $2 \sim 3$ 病日には 可能となった．本管理において利尿期は $2 \sim 3$ 病日に は終了しており, 従来の報告と比較して $1 \sim 2$ 日早 ( ${ }^{22)}$.これは術中から術直後にかけての積極的な, 諸家 の報告 ${ }^{13 / 21)}$ に比較してかなり大量な水分・Na投与が 寄与しているものと思われる. 従来の dry side の管理 では, Staring の法則を重視し, 術後肺水腫の予防には 水分および $\mathrm{Na}$ を制限するという報告 ${ }^{13)}$ が一般的であ

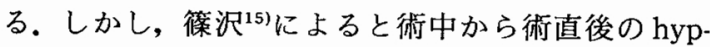
ovolemia を主体とする循環不全が術後早期の腎機能 低下の誘因となり，これによって循環血液量が変動す る結果, 換気血流不均等が発生し術後低酸素血症に関 
与すると報告しており, 術中から術直後の循環不全に 対し十分量の輸液が必要であると述べている。我々も, 術中から術直後における十分な輸液量投与によって心 房性 $\mathrm{Na}$ 利尿ペプタイドの分泌増加を介し, 組織間浮 腫の抑制と refilling がもたらす低酸素血症の軽隇が 可能であると報告してきた ${ }^{23)}$.さらに, 術後肺水腫の発 生要因は輸液量のみで規定されるのではなく, 侵襲に 伴う chemical mediator が肺の微小循環を阻害し, 肺 水腫や遷延性低酸素血症の一因となり，かつ prostag. landin $\mathrm{E}_{1}$ の投与により肺のみならず全身の呼吸循環 動態も改善されることも明らかにしている24). 以上よ り, 術後侵襲期の輸液療法は十分な細胞外液組成液と 膠質製剤の投与により循環動態を早期に安定化させる ことが侵襲期の早期離脱に重要であると思われた。

一方, TPNを施行しない分, 総投与カロリー量は, 6 病日で $20 \mathrm{kcal} / \mathrm{kg} \cdot \mathrm{day}, 9$ 病日で30 $\mathrm{kcal} / \mathrm{kg} ・ \mathrm{day}$ 越える程度しか投与されておらず，特に 2 病日までは 末梢輸夜のみのため 1,2 病日でそれぞれ $8.27,8.33$ $\mathrm{kcal} / \mathrm{kg} \cdot \mathrm{day}$ の投与量であり, 諸家の報告よりも少な い投与量であった ${ }^{13)}$. しかし, 術後の栄養指標の推移を みると TP やアルブミンは 7 病日に, RTP も 14 病日に は術前値と同等な值に回復し, かつ3-MeHis や BUN の推移も良好であった.これらの成績は, 以前の TPN 中心の栄養管理の成績と比較して遜色はなく ${ }^{25)}$, 極端 なカロリー不足に陥つているとは考え難い。近年の術 後侵襲期代謝動態の検討 ${ }^{26)}$ によると, 中等度侵襲では TPN によるエネルギーやアミノ酸投与により蛋白代 謝が改善されるが, 食道癌術後のような過大侵襲下で は投与エネルギーやアミノ酸を増量するだけでは蛋 白・エネルギー代謝上メリットはないという報告もあ る.さらに, 過大侵襲下ではエネルギ一需要は増大す るものの, これを代償するエネルギーは内因性エネル ギー基質特に体脂肪に依存することが多く, 生体のグ ルコースを中心とした外因性エネルギー基質に対する 反応性は低下しているばかりでなく, 逆に外因性グル コース投与の結果, 内因性エネルギー基質の動員を抑 制し, TCA cycle の回転を阻害する可能性も報告され ている27)28). 我々の術直後の bio-impedance を用いた 検討29)でも, 1 病日では内因性脂肪の燃焼が認められ, 従来のように術後 1 ～病日頃に投与エネルギーを一 律に増加させることはエネルギ一代謝上生体にとって 逆に stress となることも考えられる.したがって，侵 襲の離脱後に投与栄養量を増加させることが, 効率の 良い栄養投与と思われる.この際の投与経路として
我々は, ENを用いたが, 投与量の増量を慎重に行った 結果 $30 \mathrm{kcal} / \mathrm{kg} \cdot \mathrm{d}$ ay 以上の投与カロリーに達したの は 9 病日以降であった. しかし, 下痢は多くの症例で 認められたものの対症的に管理可能であり，投与量を 減量した症例は 38 名中 3 名のみで, 腹満などの副作用 は認められなかった。近年術後あるいは侵襲早期から の $\mathrm{EN}$ の有用性が報告され, 五関ら ${ }^{30)}$ は我々と同様, TPN なしで 3 病日より $\mathrm{EN}$ を開始し，6病日には $2,000 \mathrm{kcal}$ 弱の投与が可能で, RTP や3-MeHis の推移 も良好であったと報告している。我々も今回の検討を 通じ, $\mathrm{EN}$ 投与量はもう少し早期より増量可能ではな いかという感触を得ている。 また, 本管理の特筆すべ き点として, 管理の容易さが挙げられ, TPN を施行し ないことにより，頻回の血糖測定やインスリン投与の 必要がなく患者の負担も軽隇された。したがって, 術 後の栄養管理は侵襲期の早期離脱によって腸管運動の 早期回復を促すことにより積極的な EN 投与が可能 であり，必ずしも TPN を必要としないものと思われ た。

以上の術後輸液・栄養管理で最後的に問題となるの は術後合併症の発生率と思われる. 全般的に合併症の 発生率は低率であり (Table 2), 重篤な合併症や手術 死亡・在院死亡も認められず, 安全な care が施行でき たと考えている.個々の合併症をみると,他の報告 ${ }^{31321}$ に比べ特に不整脈と高ビリルビン血症の発生率が低率 であった。不整脈に関しては, 有効循環血液量維持を 目標とした術後輸液管理が, hypovolemia に起因する 不整脈の発生を予防しえたものと考えている。また, 術後高ビリルビン血症に関しては, EN 投与による腸 管粘膜萎縮予防や TPN を施行しないことで肝の代謝 上の stress がなかったことが高ビリルビン血症の発 生抑制の一因子として寄与しているものと思われ た ${ }^{33) 34)}$.

以上, 当科で施行している食道癌術後輸液栄養管理 について報告した。現在, 本管理の有用性をさらに検 討するため, TPN 併用の有無別の prospective randomized trial を施行中である.

本研究にあたり, 深甚なるご助力を頂いた当教室代謝研 究室久保居真奈美氏に感謝いたします。なお, 本論文の要旨 は第 9 回日本静脈経腸栄責研究会 (福岡), 第48回食道疾患 研究会 (福岡), 第44回日本消化器外科学会総会 (富山) に て発表した。

$$
\text { 文献 }
$$

1）飯塚紀文：治癒率の上昇を期待した食道癌手術の 
併用療法とその開発. 垣添忠生, 下山正徳 監修. 薬物療法を主体とする固形がんの集学的治療の臨 床試験研究. 協和企画通信, 東京, 1991, p142-151

2) Maesawa C, Tamura G, Suzuki Y, et al: Aberrations of tumor-suppressor genes ( $p 53$, $a p c, m c c$ and $R b$ ) in esophageal squamous-cell carcinoma. Int J Cancer $47: 21-25,1994$

3) Terashima M, Ikeda K, Kawamura $\mathrm{H}$ et al: A comparative study of ATP assay with serum. free culture and adhesive tumor cell culture system as a drug sensitivity test for human esophageal cancer. Cancer Res Therapy Control 3:297-301, 1993

4) 池田健一郎, 寺島雅典, 前沢千草ほか：内視鏡下生 検標本を用いた食道癌・胃癌に対する制癌羭感受 性試験と薬剂耐性遺伝子 mdrl m-RNA 0過剩発 現に関する検討. 消化器癌 $4: 341-345,1995$

5）石田 薫, 村上弘治：食道癌治療のプロトコール. 臨外 $42: 741-749,1987$

6）池田健一郎, 石田 薫, 佐藤信博ほか：当科におけ る胸部食道癌治療の成績と問題点. 岩手医誌 $44: 603-608,1992$

7) 岡本和美, 森 昌造, 新津頼一ほか: 栄責管理. 消 外 7:1167-1173, 1984

8）池田健一郎, 佐藤信博, 岡本和美ほか：食道癌術後 栄養管理の検討：経腸栄養を中心とした栄養管理

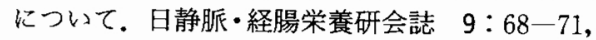
1994

9）武藤輝一：E-0651(クリニミール)の多施設による 臨床試験成績. 診療と新薬 $18: 873-884,1981$

10) Murata A, Ogawa M, Yasuda T et al: Serum interleukin 6, C-reactive protein and pancreatic secretory trypsin inhibitor (PSTI) as acute phase reactants after major thoraco-abdominal surgery. Immunol Invest $19: 271-278,1990$

11）佐山淳造, 標葉隆三郎, 横田憲一ほか：術前ステロ イド剂投与による食道癌手術後生体反応の制御。 日消外会誌 $27: 841-847,1994$

12）渡辺 寛, 加藤抱一, 日月裕司：高齢者胸部食道癌 の術後合併症発生状況および気管支ファイバーに よる肺合併症対策. 外科診療 $19: 609-615,1988$

13）日置宏士郎, 小島善嗣, 平松義文ほ加: 術後の輸 液. 外科治療 $61: 23-28,1989$

14）佐藤信博: 食道癌術後早期循環動態と低酸素血症 の検討. 岩手医誌 $42: 25-39,1990$

15）篠沢洋太郎：食道癌根治術後早期における肺・腎 機能変動に関する研究. 日外会誌 $90: 669-681$, 1989

16) Mochizuki H, Trocki O, Dominioni L et al: Mechanism of prevention of postburn hypermetabolism and catabolism by early enteral feeding. Ann Surg 200:297-310, 1984

17）斎藤英昭, 福島亮治, 林 明燦ほか：経腸栄養法：
最近の進歩. 消外 $16: 1629-1639,1993$

18) Kudsk KA, Croce MA, Fabian TC et al : Enteral versus parenteral feeding. Ann Surg 215:503-513, 1992

19) Moore FA, Feliciano DV, Andrassy RJ et al : Early enteral feeding, compared with parenteral, reduces postoperative septic complications. Ann Surg A 216: 172-183, 1992

20) Anderson JD, Moore FA, Moore EE : Enteral feeding in the critically injured patient. NCP 7:117-122, 1992

21）小島善志, 平松義文, 中川明彦ほか：上部消化管癌 手術における $\mathrm{Na}$ 投与量の検討. 日外会誌 91 : $942-949,1990$

22）安藤暢敏, 米川甫, 篠沢洋太郎ほか：食道癌患者 における術前後の循環動態の変動に関する研究. 日外会誌 $83: 624-634,1982$

23）佐藤信博, 村上弘治, 石田 薰ほか：食道癌術後循 環動態と心房性ナトリウム利尿ペプチドの変動。 臨胸外 11：465-469，1991

24）肥田圭介：食道癌術後呼吸不全に関する臨床的検 討一術中, 術後 $\mathrm{PGE}_{1}$ 投与効果に関連して一. 岩手 医誌 45：39-47，1993

25）菅原 智：食道癌根治術後の至適カロリー源とし ての糖と脂肪の併用に関する研究. 岩手医誌 $45: 1-14,1993$

26）藤崎安明, 田代亜彦, 真島吉也ほか：外科侵襲下の 高カロリー輸液 (TPN) におけるエネルギー及び アミノ酸至適投与量の検討. 日外会誌 $93: 119$ 一 132,1992

27）嶌原康行, 木内哲也, 徳永行彦ほ加：肝臟の Redox 理論. ICU と CCU 12：953-962，1988

28）石曜 謙, 田代亜彦, 山森秀夫ほか：食道癌手術後 のエネルギー基質燃焼比率. 日静脈・経腸栄養研会 誌 9:14-17, 1994

29）岡本和美, 新津頼一, 大浪優二ほ加：消化器外科手 術後の体構成成分の変化. 日静脈・経腸栄責研会誌 $4: 140-142,1989$

30）五関謹秀, 原譲, 青井東呉ほか: 高度侵襲消化 器手術後の経腸栄養管理. 日消外会誌 $26: 1169$ $-1174,1993$

31）今野 修, 手塚 徹, 武藤 淳䚾加: 食道癌術後不 整脈の検討. 日胸外会誌 $41: 45-51,1993$

32）北村道彦, 西平哲郎, 平山 克ほか：食道癌術後の 高ビリルビン血症の検討. 日消外会誌 $21: 2063$ -2068, 1988

33）片山哲夫, 田中 満, 田中紘一ほか：成熟ラットに おける肝ミトコンドリア機能に対する完全静脈栄 養 (TPN)の影響。外科と代謝・栄 24:588-593， 1990

34）辻中利政,城戸良弘，小川嘉誉ほか：食道癌術後の 高ビリルビン血症の検討. 日外会誌 $88: 939$ 946, 1987 


\title{
Postoperative Management of Infusion and Nutrition for Thoracic Esophageal Cancer Patients
}

\author{
Kenichiro Ikeda, Nobuhiro Sato, Keisuke Koeda, Eiji Meguro, Noriyuki Uesugi, \\ Satoshi Ogasawara, Kouki Otsuka, Yusuke Kimura, Chihaya Maesawa*, \\ Yasunori Yaegashi, Masanori Terashima, Kazumi Okamoto, \\ Kaoru Ishida and Kazuyoshi Saito \\ Department of Surgery 1, Iwate Medical University \\ *Department of Pathology, Division of Clinical Research Morioka National Hospital
}

Out of 38 patients who were underwent total thoracic esophagectomy under thoracolaparotomic cervical manipulation, 14 patients were assessed as to water and electrolyte metabolism and nutritional parameters, and all of them were studied about the postoperative complications under our postoperative infusion and nutritional management as follows: 1) In order to maintain stable circulation during the perioperative period, the infusion volume, whose contents were similar to extracellular fluid, was determined by the value of the preoperative cardiac index and end diastolic volume index 2) The nutrition was given by enteral feeding without TPN at the introducing dose of $5 \mathrm{kcal} / \mathrm{kg} / \mathrm{day}$ from 3 postoperative day (POD) and gradually increased at a full dose of $30 \mathrm{kcal} / \mathrm{kg} / \mathrm{day}$. Total water and sodium intake on the operation day just after surgery were significantly higher than those on other postoperative days, 5.24 $\mathrm{ml} / \mathrm{kg} / \mathrm{hr}$ and $0.56 \mathrm{mEq} / \mathrm{kg} / \mathrm{hr}$, respectively. Total calorie intake reached $30 \mathrm{kcal} / \mathrm{kg} /$ day on $9 \mathrm{POD}$. Nitrogen and potassium balances became positive on 10 and 4 POD, respectively. Total protein, albumin, prealbumin, transferrin, retinol binding protein and peripheral lymphocyte counts were the lowest on 3 POD. 3-methylhistidine urinary excretion and C-reactive protein were the highest on 3POD. All these parameters returned to the preoperative values on $14 \mathrm{POD}$. The incidences of postoperative complications were $11 \%$ of primary pulmonary complication, $8 \%$ of arrhythmia, $11 \%$ of hyperbilirubinemia, $3 \%$ of minor leakage and $3 \%$ of ileus, respectively. These results suggest that our postoperative management is simple and safety mothod against thoracic esophageal cancer surgery.

Reprint requests: Kenichiro Ikeda Department of Surgery 1, Iwate Medical University 19-1 Uchimaru, Morioka, 020 JAPAN 